\title{
Measurement report: Characterization and source apportionment of coarse particulate matter in Hong Kong: Insights into the constituents of unidentified mass and source origins in a coastal city in southern China
}

5 Yee Ka Wong ${ }^{1, *}$, Kin Man Liu $^{2}$, Claisen Yeung ${ }^{2}$, Kenneth K. M. Leung ${ }^{3}$, Jian Zhen Yu ${ }^{1,4, *}$

${ }^{1}$ Division of Environment and Sustainability, Hong Kong University of Science and Technology, Clear Water Bay, Kowloon, Hong Kong

${ }^{2}$ Environmental Central Facility, Hong Kong University of Science and Technology, Clear Water Bay, Kowloon, Hong Kong ${ }^{3}$ Hong Kong Environmental Protection Department, 15/F, East Wing, Central Government Offices, 2 Tim Mei Avenue, Tamar,

10 Hong Kong

${ }^{4}$ Department of Chemistry, Hong Kong University of Science and Technology, Clear Water Bay, Kowloon, Hong Kong

Correspondence to: Yee Ka Wong (envrykwong@ust.hk); Jian Zhen Yu (jian.yu@ust.hk)

Abstract. Coarse particulate matter (i.e., PM with aerodynamic diameter between 2.5 and 10 micrometers or PM $\mathrm{P}_{\text {coarse}}$ ) has been increasingly recognized of its importance in $\mathrm{PM}_{10}$ regulation because of its growing proportion in $\mathrm{PM}_{10}$ and the accumulative evidence for its adverse health impact. In this work, we present comprehensive $\mathrm{PM}_{\text {coarse }}$ speciation results obtained through a one-year long (January 2020-February 2021) joint $\mathrm{PM}_{10}$ and $\mathrm{PM}_{2.5}$ chemical speciation study in Hong Kong, a coastal and highly urbanized city in southern China. The annual average concentration of $\mathrm{PM}_{\text {coarse }}$ is $14.9 \pm 8.6 \mu \mathrm{g} \mathrm{m}^{-3}$ ( \pm standard deviation), accounting for $45 \%$ of $\mathrm{PM}_{10}\left(32.9 \pm 18.5 \mu \mathrm{g} \mathrm{m}^{-3}\right)$. The measured chemical components explain $\sim 75 \%$ of the $\mathrm{PM}_{\text {coarse }}$ mass. The unexplained part is contributed by unmeasured geological components and residue liquid water content, supported by analyses by positive matrix factorization (PMF) and the thermodynamic equilibrium model ISORROPIA II. The $\mathrm{PM}_{\text {coarse }}$ mass is apportioned to four sources resolved by PMF, namely soil dust, copper-rich dust, fresh sea salt, and an aged sea salt factor containing secondary inorganic aerosols (mostly nitrate). Back-trajectory cluster analysis reveals significant variations in source contributions with the air mass origin. Under the influence of marine air mass, $\mathrm{PM}_{\text {coarse }}$ is the lowest (average $=8.0 \mu \mathrm{g} \mathrm{m}^{-3}$ ) and sea salt is the largest contributor $(47 \%)$, followed by the two dust factors (38\% in total).

25 When the site receives air mass from the northern continental region, $\mathrm{PM}_{\text {coarse }}$ increased substantially to $21.2 \mu \mathrm{g} \mathrm{m}^{-3}$, with the two dust factors contributing $90 \%$ of the aerosol mass. The potential dust source areas are mapped using the ConcentrationWeighted Trajectory technique, showing either the Greater Bay Area or the greater part of southern China as the origin of fugitive dust emissions leading to elevated ambient $\mathrm{PM}_{\text {coarse }}$ loadings in Hong Kong. This study, first of this kind in our region, provides highly relevant guidance to other locations with similar monitoring needs. Additionally, the study findings point to the needs for further research on the sources, transport, aerosol processes, and health effects of $\mathrm{PM}_{\text {coarse }}$. 


\section{Introduction}

Coarse particulate matter $\left(\mathrm{PM}_{\text {coarse}}\right)$, defined as $\mathrm{PM}$ with aerodynamic diameter of $2.5-10 \mu \mathrm{m}$ in the World Health Organization's air quality guidelines, play important roles in air quality, public health, and global climate. Progress in reducing fine PM $\left(\mathrm{PM}_{2.5}\right)$ pollution in the past makes it increasingly important to explore possibilities to control $\mathrm{PM}_{\text {coarse }}$ for $\mathrm{PM}_{10}$ regulation. In the United States, $\mathrm{PM}_{\text {coarse }}$ constitutes half of $\mathrm{PM}_{10}$ mass nationwide in 2012-2016 (Hand et al., 2019). The relative contribution of $\mathrm{PM}_{\text {coarse }}$ to $\mathrm{PM}_{10}$ mass was reported to increase by $0.7-1.2 \%$ annually over 2000-2016. While the health impact of $\mathrm{PM}_{\text {coarse }}$ examined by earlier epidemiological studies were inconclusive (Adar et al., 2014), more recent

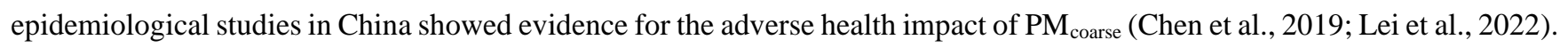
The health impact of $\mathrm{PM}_{\text {coarse }}$ depends on the exposure to and concentration and composition of $\mathrm{PM}_{\text {coarse, }}$ which may explain the varied health implications found in different studies (Adar et al., 2014; Chen et al., 2019; Lei et al., 2022).

Understanding the sources of $\mathrm{PM}_{\text {coarse }}$ is important for developing control strategies. $\mathrm{PM}_{\text {coarse }}$ is primarily generated by mechanical processes such as wind and erosion, and the sources can be naturally and anthropogenically related. The natural processes include ejection of sea spray, resuspension of soil dust, and release of plant-related particles, etc. Common anthropogenic $\mathrm{PM}_{\text {coarse }}$ sources include road dust resuspended by road traffic, brake/tire wearing, construction dust, fly ash and metallurgical process. While $\mathrm{PM}_{\text {coarse }}$ are mostly directly emitted, certain components in $\mathrm{PM}_{\text {coarse }}$ can be related to secondary formation. For example, nitrate in the coarse mode is formed by the reaction between nitric acid $\left(\mathrm{HNO}_{3}\right)$ from oxidation of $\mathrm{NO}_{\mathrm{x}}$ and preexisting alkaline aerosols (e.g., sea salt and dust). A recent study showed that mineral dust can serve as a medium for rapid secondary inorganic and organic aerosol formation under high photochemical activity and relative humidity conditions, which has important implications to the life cycle of secondary aerosols (Xu et al., 2020). PM coarse $_{\text {also exerts an }}$ impact on earth's climate because of its continuous loading in the atmosphere and its ability to scatter and absorb radiation or act as cloud condensation and ice nuclei (USEPA, 2019).

As a coastal and highly urbanized city and being a part of the Guangdong-Hong Kong-Macao Greater Bay Area (GBA) economic and business hub in southern China, Hong Kong is facing atmospheric PM pollution originated from both local and regional influence. Continuous improvement in local and regional PM concentrations is noted in the last few years (HKEPD,

55 2020). The ambient $\mathrm{PM}_{10}$ concentration has been reduced by $24 \%$ from $42 \mu \mathrm{g} \mathrm{m}^{-3}$ in 2012 to $32 \mu \mathrm{g} \mathrm{m}^{-3}$ in 2019 . The reduction was contributed mostly by $\mathrm{PM}_{2.5}$, which correspondingly decreased by $32 \%$ from 28 to $19 \mu \mathrm{g} \mathrm{m}^{-3}$. By taking the difference

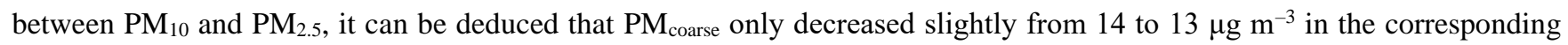
period. Because of the disproportionate reduction in $\mathrm{PM}_{2.5}$, the relative contribution of $\mathrm{PM}_{\text {coarse }}$ to $\mathrm{PM}_{10}$ increased from $33 \%$ in 2012 to $41 \%$ in 2019. The analysis has two important implications. First, $\mathrm{PM}_{2.5}$ and $\mathrm{PM}_{\text {coarse }}$ in Hong Kong have different

60 sources. Second, it is important to characterize the sources of $\mathrm{PM}_{\text {coarse }}$, which has gained increasing importance in $\mathrm{PM}_{10}$ contribution.

Previous $\mathrm{PM}_{\text {coarse }}$ studies in Hong Kong were focused on suburban coastal area (Cohen et al., 2004), roadside environment (Cheng et al., 2015), and public transport micro-environments (Jiang et al., 2017). These studies provide limited representation 
of the general $\mathrm{PM}_{\text {coarse }}$ pollution characteristics given the predisposition to the influence by nearby sources; for example, sea spray in coastal environment or traffic-related emissions in roadside environment. Hong Kong has been operating a $\mathrm{PM}_{10}$ monitoring network since 1998, which consists of six general stations and one roadside station. The network collects $24 \mathrm{~h}$ samples on quartz fiber filters on a 1 in 6 days schedule by high-volume (HV) samplers, which operate at a flow rate of 1.13 $\mathrm{m}^{3} \mathrm{~min}^{-1}$. The HV quartz fiber filters are used for gravimetric analysis and chemical speciation including major ions, elements, organic carbon (OC), and elemental carbon (EC) (Zhang et al., 2018). The $\mathrm{PM}_{2.5}$ speciation network in Hong Kong started to operate in 2011. $\mathrm{PM}_{2.5}$ samples are collected on Teflon filters and quartz fiber filters by middle-volume samplers which operate at a flow rate of $16.7 \mathrm{~L} \mathrm{~min}$. The Teflon filters are used for gravimetric and elemental analyses while the quartz fiber filters are analyzed for major ions, OC and EC (Yu and Zhang, 2018). It should be noted that Si and Ti, which are important markers for quantifying dust contribution, are not determined in $\mathrm{PM}_{10}$ samples due to the high background in ICP-OES analysis. On the other hand, the $\mathrm{PM}_{2.5}$ network employs X-ray fluorescence technique for elemental analysis, and thus has no difficulty in reporting the concentrations of these two elements. Additionally, carbonaceous components in $\mathrm{PM}_{10}$ and $\mathrm{PM}_{2.5}$ are determined using different thermal methods (NIOSH protocol for $\mathrm{PM}_{10}$ and IMPROVE protocol for $\mathrm{PM}_{2.5}$ ). In view of the aforementioned, the two PM monitoring networks in Hong Kong adopt different sampling and laboratory analysis protocols which would introduce uncertainties to the analysis results. The possibility of deriving a solid understanding of the composition and sources of $\mathrm{PM}_{\text {coarse }}$ using existing data sets certainly requires further investigation.

80 We present in this work the first joint $\mathrm{PM}_{10}$ and $\mathrm{PM}_{2.5}$ speciation effort in Hong Kong in which all the sampling and chemical analysis work were conducted using identical methods and by the same laboratory. The aim is to obtain high quality

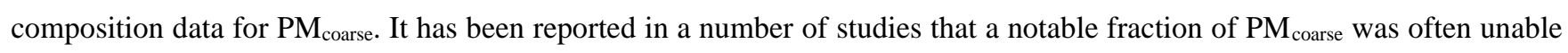
to be identified. Cheung et al. (2011) reported an up to $25 \%$ contribution from such unidentified mass in Los Angeles area, while Putaud et al. (2010) reported 6-43\% in urban Europe. Although it has been suggested that the unidentified mass was associated with liquid water content and mineral components, their exact contributions have remained largely uncharacterized. By using positive matrix factorization (PMF), we showed that the unidentified masses can be allocated to the resolved sources, providing qualitative and quantitative information on their origins. We propose the unidentified mass in $\mathrm{PM}_{\text {coarse }}$ in our study region is mainly composed of unmeasured mineral components and liquid water content. The measured $\mathrm{PM}_{\text {coarse }}$ in its entirety was successfully apportioned to various contributing sources by PMF, and the potential source origins are identified using backward air mass trajectory analysis. With the robust source apportionment analysis, we found that fugitive dust associated with regional influence is the dominant contributor of high $\mathrm{PM}_{\text {coarse }}$ loading in Hong Kong. The methodology and results from this study can serve to provide guidance to other locations with similar monitoring needs. 


\section{Methods}

\subsection{Ambient sampling}

95 Aerosol sampling was conducted in Hong Kong at the Tuen Mun Air Quality Monitoring Station (TMC AQMS), which is located on the rooftop of a public library building $\left(22^{\circ} 23^{\prime} 28.4^{\prime \prime} \mathrm{N}, 113^{\circ} 58^{\prime} 37.1^{\prime \prime} \mathrm{E}, \sim 30 \mathrm{~m}\right.$ above ground level). The AQMS is situated in the northwestern part of the Hong Kong. The city, with a territory area of $\sim 1110 \mathrm{~km}^{2}$ and a population of $\sim 7.5$ million, is part of the bigger economic and business hub, the Greater Bay Area (GBA) $\left(\sim 56,000 \mathrm{~km}^{2}\right.$, population of $\sim 85$ million), in Guangdong province of China. Located in the sub-tropical region along the southeast coast of China, Hong Kong exhibits a season-dependent air pollution characteristics that is closely related to the seasonal evolution of the East Asian Monsoon system. Generally, air pollution during colder seasons is more severe than in warm seasons. This will be elaborated when the measurement results are discussed.

Twenty-four-hour samples (midnight to midnight) for $\mathrm{PM}_{10}$ and $\mathrm{PM}_{2.5}$ were collected simultaneously on a once every three days schedule. The sampling lasted for over a year from 18 January 2020 to 9 February 2021. In each sampling event, one $47-$ $\mathrm{mm}$ Teflon and one 47-mm quartz fiber filter samples were collected for each of the PM size fractions. The sample collection was accomplished by deploying two pairs of federal reference method samplers operated at a flow rate of $16.7 \mathrm{~L} \mathrm{~min}{ }^{-1}$. The first pair (Partisol Plus 2025, Thermo Fisher Scientific, MA, USA) were equipped with $\mathrm{PM}_{10}$ sampling inlets to collect $\mathrm{PM}_{10}$, whereas in the second pair (BGI PQ200, Mesa Labs, CO, USA) the Very Sharp Cut Cyclones were installed downstream of the $\mathrm{PM}_{10}$ inlets for $\mathrm{PM}_{2.5}$ fine particles collection. Field blanks (Teflon and quartz) were collected during the last sampling of each month. All the filter samples were delivered back to the balance laboratory for conditioning followed by gravimetric analysis within one week. The filters were subsequently stored at $-20^{\circ} \mathrm{C}$ until chemical analysis.

\subsection{Mass and chemical composition determination for $\mathbf{P M}_{\text {coarse }}$}

The mass concentration and chemical composition of $\mathrm{PM}_{\text {coarse }}$ are determined as the difference between $\mathrm{PM}_{10}$ and $\mathrm{PM}_{2.5}$ measurements. The $\mathrm{PM}_{10}$ and $\mathrm{PM}_{2.5}$ samples were speciated using the identical protocol that has been adopted in the Hong

115 Kong $\mathrm{PM}_{2.5}$ speciation network for regular monitoring of $\mathrm{PM}_{2.5}$ composition since 2011 (Huang et al., 2014). The protocol is based on the speciation guideline by the U.S. Environmental Protection Agency (Chow and Watson, 1998). The design of joint sampling and chemical analysis of $\mathrm{PM}_{10}$ and $\mathrm{PM}_{2.5}$ eliminates data incompatible issues observed for data from the existing networks.

All the gravimetric and chemical analyses of the filter samples were conducted by the same laboratory in the Hong Kong

120 University of Science and Technology. PM mass concentration was determined on the Teflon filter samples by gravimetry with a digital microbalance (Sartorius AG, Model MC 5-0CE, Göttingen, Germany, sensitivity of $\pm 1 \mu \mathrm{g}$ ) under a temperatureand relative humidity-controlled environment $\left(20-23{ }^{\circ} \mathrm{C}\right.$ and $\left.30-40 \%\right)$. Elements from $\mathrm{Al}$ to $\mathrm{U}$ were quantified on the Teflon filters by an energy dispersive X-ray fluorescence spectrometer (ED-XRF) (Epsilon 5, PANalytical, The Netherlands). OC and 
EC were quantified on the quartz fiber filters with an aerosol carbon analyzer (DRI Model 2001A, Atmoslytic, Calabasas, CA, Ionic species including $\mathrm{Cl}^{-}, \mathrm{NO}_{3}{ }^{-}, \mathrm{SO}_{4}{ }^{2-}, \mathrm{NH}_{4}{ }^{+}, \mathrm{Na}^{+}, \mathrm{Mg}^{2+}, \mathrm{K}^{+}$and $\mathrm{Ca}^{2+}$ were analyzed on the quartz fiber filters by ion chromatography (IC) (Dionex ICS-1100, Thermo Fisher Scientific, MA, USA).

The species concentrations in $\mathrm{PM}_{10}$ and $\mathrm{PM}_{2.5}$ samples were blank corrected. The measurement precisions were propagated from the precisions of volumetric measurements during sampling, chemical analyses, and field blank variability (Yu and Zhang, 2018). Duplicate analysis of the aerosol samples was performed for every 10 measurements to derive precisions for the chemical analyses. The measurement precisions for $\mathrm{PM}_{\text {coarse }}$ speciation were propagated from the precisions of the $\mathrm{PM}_{10}$ and $\mathrm{PM}_{2.5}$ measurements.

\subsection{Source apportionment by positive matrix factorization}

Source identification and quantification for $\mathrm{PM}_{\text {coarse }}$ was conducted by analyzing the speciation data matrix with positive matrix

factorization (PMF). PMF decomposes the speciation data matrix into factor profiles and factor contributions matrices with non-negative constraints, with the objective of minimizing the uncertainty weighted differences between observed and apportioned species concentrations represented by an objective function Q (Paatero and Tapper, 1994). The USEPA PMF 5.0 software was used for this undertaking (Norris et al., 2014). The fitting species include total $\mathrm{PM}_{\text {coarse }}$ mass and a suite of chemical species including $\mathrm{Na}^{+}, \mathrm{NH}_{4}{ }^{+}, \mathrm{Mg}^{2+}, \mathrm{Cl}^{-}, \mathrm{NO}_{3}{ }^{-}, \mathrm{SO}_{4}{ }^{2-}, \mathrm{OC}, \mathrm{EC}, \mathrm{Al}, \mathrm{Si}, \mathrm{K}, \mathrm{Ca}, \mathrm{Ti}, \mathrm{V}, \mathrm{Mn}, \mathrm{Fe}, \mathrm{Ni}, \mathrm{Cu}, \mathrm{Zn}$, and $\mathrm{Pb}$. The

140 uncertainty of $\mathrm{PM}_{\text {coarse }}$ mass was tripled to downweigh its influence in the source apportioning. This allows the total $\mathrm{PM}_{\text {coarse }}$ mass to be apportioned mainly according to its covariance with other species. Concentrations below the method detection limit (MDL) were replaced by $1 / 2 \times$ MDL with corresponding uncertainties set to be $5 / 6 \times$ MDL as recommended in the PMF user manual. The input speciation data matrix consists of $123 \mathrm{PM}_{\text {coarse }}$ samples.

\section{Results and discussion}

\section{3.1 Abundance and composition of PMcoarse}

\subsubsection{Annual average and comparison with other locations}

The speciation data quality was evaluated by examining the consistency between species concentrations measured by different methods; for example, gravimetric mass vs. mass from continuous monitor, gravimetric mass vs. reconstructed mass, $\mathrm{SO}_{4}{ }^{2-}$ vs. total $\mathrm{S}$, and $\mathrm{K}^{+}$vs. total $\mathrm{K}$, etc. Deming regression was applied in the examination using the Scatter Plot computer program 150 developed by $\mathrm{Wu}$, which is available at https://doi.org/10.5281/zenodo.832417 (Wu and Yu, 2018). Details of the evaluation are provided in Sect. S1 in the Supplement. In short, the evaluation shows the speciation data are of adequate quality for the ensuing analyses. 
The study-wide average concentration of $\mathrm{PM}_{\text {coarse }}$ is $14.9 \pm 8.6 \mu \mathrm{g} \mathrm{m}^{-3}$ ( \pm standard deviation), accounting for $45 \%$ of ambient $\mathrm{PM}_{10}\left(32.9 \pm 18.5 \mu \mathrm{g} \mathrm{m}^{-3}\right)$. The daily concentrations range from 2.9 to $40.4 \mu \mathrm{g} \mathrm{m}^{-3}$. The contribution of geological material is

estimated by assuming the crustal elements are in oxide forms, i.e., $1.89 \times[\mathrm{Al}]+2.14 \times[\mathrm{Si}]+1.2 \times[\mathrm{K}]+1.4 \times[\mathrm{Ca}]+1.67 \times[\mathrm{Ti}]$ $+1.43 \times[\mathrm{Fe}]$. This component has the largest contribution, making up $5.2 \mu \mathrm{g} \mathrm{m}^{-3}$ or $35 \%$ of the $\mathrm{PM}_{\text {coarse }}$ mass. The next important component is nitrate $\left(2.2 \mu \mathrm{g} \mathrm{m}{ }^{-3}, 15 \%\right)$, followed by sea salt-related ions (i.e., $\mathrm{Na}^{+}, \mathrm{Mg}^{2+}$, and $\left.\mathrm{Cl}^{-}\right)$and organics ( $2 \times[\mathrm{OC}])$, which represent $11 \%$ and $8 \%$, respectively. The composition forms a stark contrast with that of $\mathrm{PM}_{2.5}(18.0 \pm 11.2$ $\left.\mu \mathrm{g} \mathrm{m}^{-3}\right)$, in which carbonaceous components $(1.6 \times[\mathrm{OC}]$ and $\mathrm{EC}, 41 \%)$ and secondary ions $\left(\mathrm{NH}_{4}{ }^{+}, \mathrm{NO}_{3}{ }^{-}\right.$, and $\left.\mathrm{SO}_{4}{ }^{2-}, 38 \%\right)$ are the major components. The difference is consistent with combustion and secondary aerosol formation processes being the major sources of fine particles, whereas coarse particles are primarily generated by mechanical processes.

The annual average concentrations of $\mathrm{PM}_{\text {coarse }}$ and selected major components measured in this study are compared with those in other locations in Table 1. Only studies that spanned at least one year or more and had all major species measured (i.e., elements, ions, $\mathrm{OC}$ and EC) are considered. Our $\mathrm{PM}_{\text {coarse }}$ level is amid those in other urban locations, more than 2 times higher than Milan in Italy and $\sim 5 \mathrm{~g} \mathrm{~m}^{-3}$ higher than Central Los Angeles, and only half of that in Casa Grande in Arizona and a tenth of Lahore in Pakistan. Our concentration is also comparable to two roadside studies carried out in Bern in Switzerland and in London and Birmingham in the UK. We note the $\mathrm{PM}_{\text {coarse }}$ concentration in a Hong Kong roadside study is $\sim 10 \mu \mathrm{g} \mathrm{m}^{-3}$ higher than the current study. Yet a straightforward urban vs. roadside comparison is not feasible given the roadside measurement was conducted more than 15 years ago. We also note that all the cited measurements were taken at least a decade ago. The lack of more recent measurements highlights the need for more $\mathrm{PM}_{\text {coarse }}$ speciation effort, considering the growing importance of $\mathrm{PM}_{\text {coarse }}$ in aerosol mass loading and health effect contributions as $\mathrm{PM}_{2.5}$ has been controlled effectively in many locations. Our $\mathrm{PM}_{\text {coarse }}$ concentration is also 3-4 times lower than that measured in desert area in Arizona but one-third higher than a desert-like area in Lancaster in Los Angeles.

Geological material is the single largest component in $\mathrm{PM}_{\text {coarse }}$ across all studies including ours, accounting for roughly 30-50

$175 \%$ (Lahore shows $74 \%$ ), underlining the importance in identifying fugitive dust sources (e.g., natural vs. anthropogenic) for effective mitigation of $\mathrm{PM}_{\text {coarse. }}$ We note that our nitrate concentration is the highest among all studies (except for the Lahore

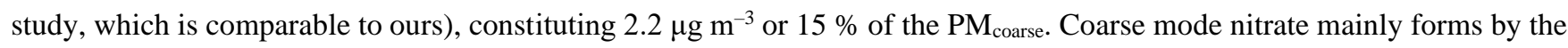
uptake of $\mathrm{HNO}_{3}$ by pre-existing alkaline particles forming $\mathrm{NaNO}_{3}$ in reaction with sea salt and $\mathrm{Ca}\left(\mathrm{NO}_{3}\right)_{2}$ with soil dust. Our total carbon level of $0.7 \mu \mathrm{g} \mathrm{C} \mathrm{m}^{-3}$ is among the lowest compared to other studies, with $86 \%$ of it coming from OC. A quarter of $\mathrm{PM}_{\text {coarse }}$ mass is regarded as unidentified in this study. The percentage share is among those observed in other studies, which range between $8 \%$ and $38 \%$. The nature of the unidentified mass will be discussed in Sect. 3.2.2.

\subsubsection{Seasonal variations in $\mathbf{P M}_{\text {coarse }}$ mass and composition}

The seasonal evolution of weather in Hong Kong is largely driven by the East Asian Monsoon system. Correspondingly, the atmospheric PM pollution in Hong Kong displays a distinct seasonal characteristic. In general, the PM loading in summer is 
mainly governed by local emissions due to the prevailing southerlies carrying clean marine air mass. In winter, the prevailing northerlies place Hong Kong under the immediate downwind of the continental region with intense industrial and agricultural activities. Under this situation, the PM loading is affected by both local and regional sources. The transient seasons - spring and fall - have more mixed wind directions. The seasonal contrast in precipitation frequency and ambient temperature, both being higher in summer and lower in winter, also contributes to the variation in PM concentration across different seasons (Louie et al., 2005; Yu et al., 2004).

The sampling period in this study is divided into four seasons based on the observed meteorological and weather patterns as analyzed in Sect. S2 in the Supplement. Table 2 lists the starting and ending dates of individual seasons, along with the seasonal averages of PM concentrations and several meteorological parameters. Note that the two winter periods at the beginning and the end of the sampling program are regarded as two different winter periods considering the variability in weather conditions and that they span mostly different calendar months.

Figure 1 presents the $\mathrm{PM}_{\text {coarse }}$ concentration and composition by season. The $\mathrm{PM}_{\text {coarse }}$ exhibits a significant variation across different seasons, ranging from the lowest $8.1 \mu \mathrm{g} \mathrm{m}^{-3}$ in summer to the highest $24.8 \mu \mathrm{g} \mathrm{m}^{-3}$ in second winter. Washout by precipitation plausibly play a role in the seasonal contrast, given that summer takes up $75 \%$ of the rainfall for the whole study period (Table 2). Mixing layer height appears to play an insignificant role in controlling the variation in PM $_{\text {coarse }}$ level. For example, although the mixing height in the first winter is the lowest among all seasons $(509 \pm 402 \mathrm{~m})$ while that in the second winter is the highest $(874 \pm 408 \mathrm{~m})$, the $\mathrm{PM}_{\text {coarse }}$ in the latter is more than twice higher than the former. The wind speed also shows small variation across the seasons, with a range of 1.9 to $2.3 \mathrm{~m} \mathrm{~s}^{-1}$. This range corresponds to a Beaufort Scale Number of 1-2, referring to the light wind condition. The meteorological data imply changes in emission pattern and/or air mass origin are likely responsible for the seasonal variation in $\mathrm{PM}_{\text {coarse }}$ levels.

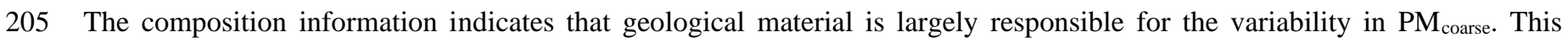
component takes up 22-43\% of the $\mathrm{PM}_{\text {coarse }}$ mass. The seasonal contrast in the contribution of this component could be attributed to enhanced wet deposition in warmer season and elevated contribution from regional transport in colder season. The unidentified mass also represents a major component in most seasons (except spring), accounting for 20-32\% of $\mathrm{PM}_{\text {coarse }}$ mass. Like geological material, this fraction has a significantly enhanced contribution in the colder season compared to the warmer season. As for other components, nitrate has the highest absolute contribution in spring and lowest in summer (3.2 vs. $1.2 \mu \mathrm{g} \mathrm{m}^{-3}$ ). Organics are the highest in the second winter and lowest in the first winter, showing an order of magnitude difference ( 2.5 vs. $0.2 \mu \mathrm{g} \mathrm{m}^{-3}$ ). The concentrations of sea salt-related ions (i.e., $\mathrm{Na}^{+}, \mathrm{Mg}^{2+}$, and $\mathrm{Cl}^{-}$) are higher in the warmer season than that in colder season, which is consistent with the enhanced influence of marine air mass in the warmer season. 
https://doi.org/10.5194/acp-2021-1030

Preprint. Discussion started: 22 December 2021

(c) Author(s) 2021. CC BY 4.0 License.
Atmospheric

Chemistry

and Physics

Discussions

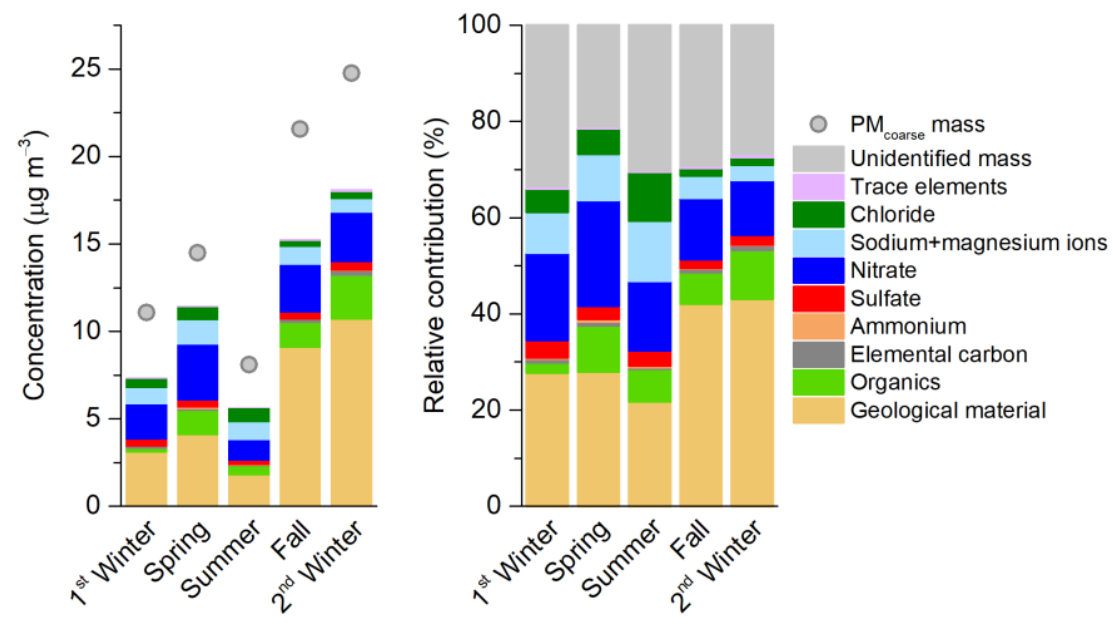

215 Figure 1. Seasonal variations in concentration and composition of PM $\mathbf{M}_{\text {coarse }}$ observed at the Tuen Mun Air Quality Monitoring Station in Hong Kong. The left and right panels show the results in absolute concentration and relative contribution, respectively.

Table 1. Comparison of $\mathbf{P M}$ coarse concentration and major composition in microgram per cubic meter (percentage contribution to

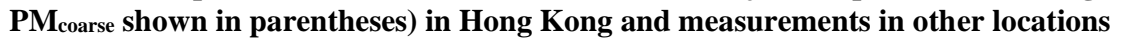

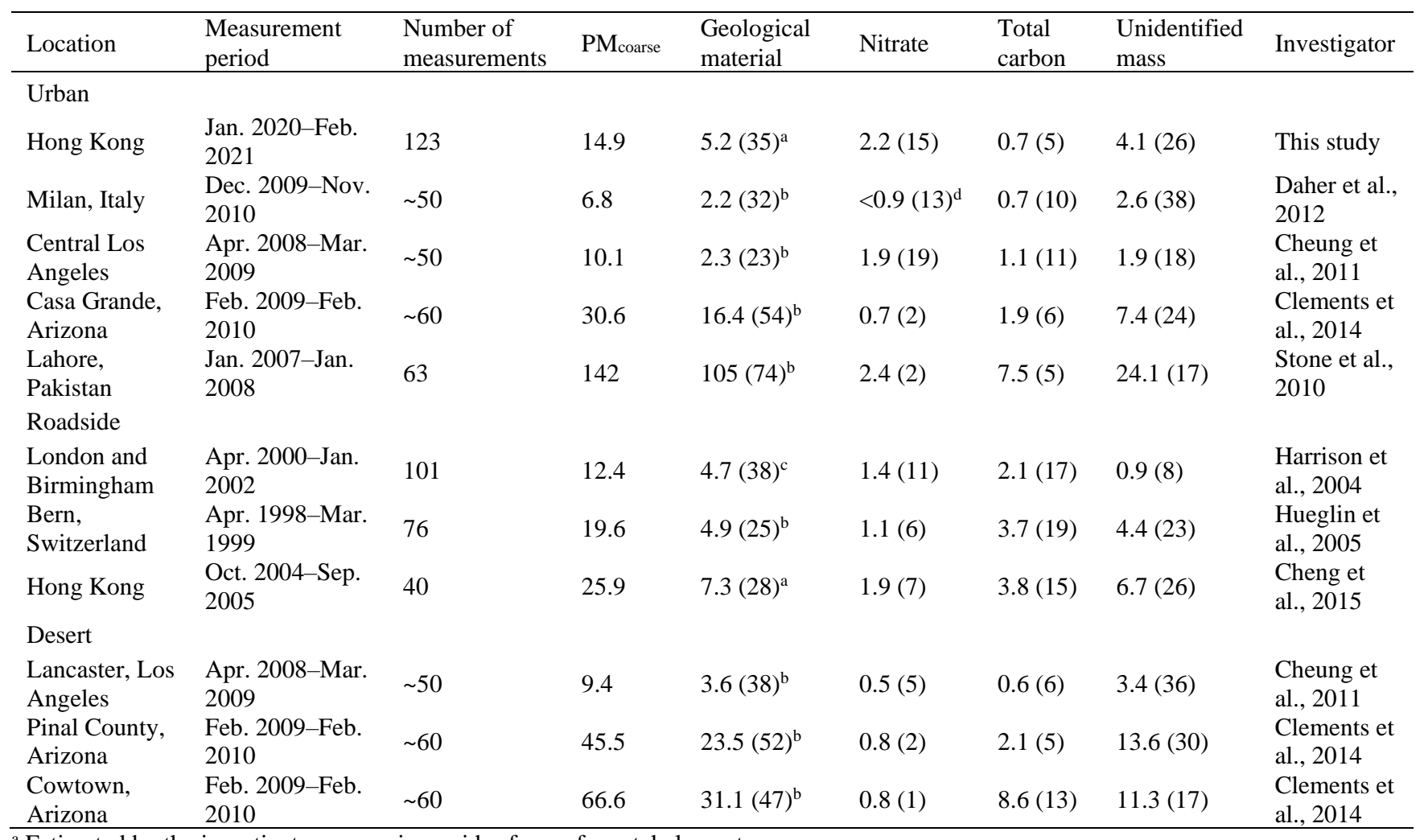

${ }^{a}$ Estimated by the investigators assuming oxides form of crustal elements.

${ }^{\mathrm{b}}$ Estimated by the investigators assuming $[\mathrm{Si}]=3.4 \times[\mathrm{Al}]$ since $\mathrm{Si}$ was not measured. 
${ }^{\mathrm{c}}$ Estimated by the investigators using $\mathrm{Ca}$ and $\mathrm{Fe}$ as the markers for gypsum and soil dust, respectively.

${ }^{\mathrm{d}}$ Only aggregate ions concentration was reported by the investigators.

Table 2. Summary of season division, PM concentrations, and meteorological parameters in Tuen Mun during the sampling period

\begin{tabular}{|c|c|c|c|c|c|c|c|c|c|}
\hline Season & Period & $\begin{array}{l}\text { Number } \\
\text { of aerosol } \\
\text { samples } \\
\end{array}$ & $\begin{array}{l}\text { PM }_{\text {coarse }} \\
\left(\mu \mathrm{g} \mathrm{m}^{-3}\right)\end{array}$ & $\begin{array}{l}\mathrm{PM}_{2.5} \\
\left(\mu \mathrm{g} \mathrm{m}^{-3}\right)\end{array}$ & $\begin{array}{l}\text { Temperature } \\
\left({ }^{\circ} \mathrm{C}\right)\end{array}$ & $\begin{array}{l}\text { Relative } \\
\text { humidity } \\
(\%)\end{array}$ & $\begin{array}{l}\text { Wind } \\
\text { speed } \\
\left(\mathrm{m} \mathrm{s}^{-1}\right)\end{array}$ & $\begin{array}{l}\text { Total } \\
\text { precipitation } \\
(\mathrm{mm})\end{array}$ & $\begin{array}{l}\text { Mixing } \\
\text { height } \\
(\mathrm{m})\end{array}$ \\
\hline $\begin{array}{l}\text { First } \\
\text { winter }\end{array}$ & $\begin{array}{l}18 \text { Jan. }-9 \text { Mar. } \\
2020\end{array}$ & 16 & 11.1 & 16.7 & $18.7 \pm 3.7$ & $76 \pm 14$ & $1.9 \pm 1.3$ & 29.2 & $509 \pm 402$ \\
\hline Spring & $\begin{array}{l}10 \text { Mar.-17 } \\
\text { May } 2020\end{array}$ & 23 & 14.5 & 19.2 & $23.1 \pm 3.6$ & $81 \pm 13$ & $2.1 \pm 1.3$ & 72.1 & $742 \pm 467$ \\
\hline Summer & $\begin{array}{l}18 \text { May-7 Oct. } \\
2020\end{array}$ & 42 & 8.1 & 9.5 & $28.1 \pm 2.0$ & $82 \pm 10$ & $2.3 \pm 1.3$ & 315.7 & $837 \pm 363$ \\
\hline $\begin{array}{l}\text { Second } \\
\text { winter }\end{array}$ & $\begin{array}{l}29 \text { Nov. } 2020-9 \\
\text { Feb. } 2021\end{array}$ & 24 & 24.8 & 29.5 & $16.4 \pm 3.8$ & $60 \pm 17$ & $2.3 \pm 1.6$ & 0.0 & $874 \pm 408$ \\
\hline
\end{tabular}

\subsubsection{Source identification by PMF analysis}

For the source apportionment analysis by PMF, the 4-factor solution was determined to be optimal by examining the mathematical outputs and physical interpretability of the resolved factor profiles in individual PMF solutions. Details of the examination are provided in Sect. S3 in the Supplement. The factor profiles are shown in Fig. 2. The first factor is clearly associated with fugitive dust, as indicated by the high abundance of crustal elements (e.g., $\mathrm{Al}, \mathrm{Si}, \mathrm{Ca}, \mathrm{Ti}$, and Fe). The elemental ratios (e.g., $\mathrm{Al} / \mathrm{Si}, \mathrm{Ca} / \mathrm{Si}$, and $\mathrm{Fe} / \mathrm{Si}$ ) of this profile are similar to those of the local paved road dust samples reported by Ho et al. (2003). However, the ratios could also be a result of mixing of different dust types. The presence of carbonaceous components is suggestive of deposition of vehicular exhaust on road dust, and OC can also be linked to biological components in soil or vegetative debris emissions. Zn can be associated with tire wear (Pant and Harrison, 2013) or metallurgical process.

Given the various characters this profile possesses, this factor is named soil dust.

The second factor is to a certain degree similar to the first factor. It contains notable amount of OC, $\mathrm{EC}, \mathrm{Ca}, \mathrm{Fe}$ and $\mathrm{Zn}$, suggesting it is also a dust-related source. The main difference is that this factor is depleted in $\mathrm{Al}, \mathrm{Si}$, and $\mathrm{K}$ and contains a high loading of $\mathrm{Cu}$. $\mathrm{Cu}$ was reported to be a marker for brake wear, which is generated from the abrasion of brake lining material and brake discs (Pant and Harrison, 2013). Cu can also be associated with metallurgical process. Another characteristic element in this factor is $\mathrm{Ca}$. This element is enriched in construction dust because of the use of cementitious materials. The presence of OC and EC again points to the possible presence of road traffic and/or biological aerosols. For the lack of a better alternative name, the second factor is termed $\mathrm{Cu}$-rich dust based on its characteristic $\mathrm{Cu}$ peak.

The third factor is marked by the high loading of $\mathrm{Cl}^{-}$with additional presence of $\mathrm{Na}^{+}$and $\mathrm{Mg}^{2+}$, which are strong indicators for fresh sea salt. The molar equivalent of $\mathrm{Cl}^{-}$is balanced by that of $\mathrm{Na}^{+}$and $\mathrm{Mg}^{2+}$, and it has an anion-to-cation equivalence 
245 ratio of 0.99 , adding credence to the validity of this factor. The last factor is loaded with a substantial fraction of $\mathrm{Na}^{+}$and $\mathrm{Mg}^{2+}$, which are markers for sea salt. The absence of $\mathrm{Cl}^{-}$and presence of $\mathrm{NO}_{3}{ }^{-}$indicate this factor specifically represents aged sea salt, given that $\mathrm{Cl}^{-}$in sea salt is actively depleted by gaseous $\mathrm{HNO}_{3}$ forming nonvolatile $\mathrm{NaNO}_{3}$. This factor is termed aged sea salt mixed with secondary inorganic aerosols.

The stability of the PMF solution has been tested against the bootstrapping and displacement functions embedded in the PMF software. The results show that the PMF solution is statistically robust for source analysis. Details of the uncertainty estimation are summarized in Table S2 in the Supplement.

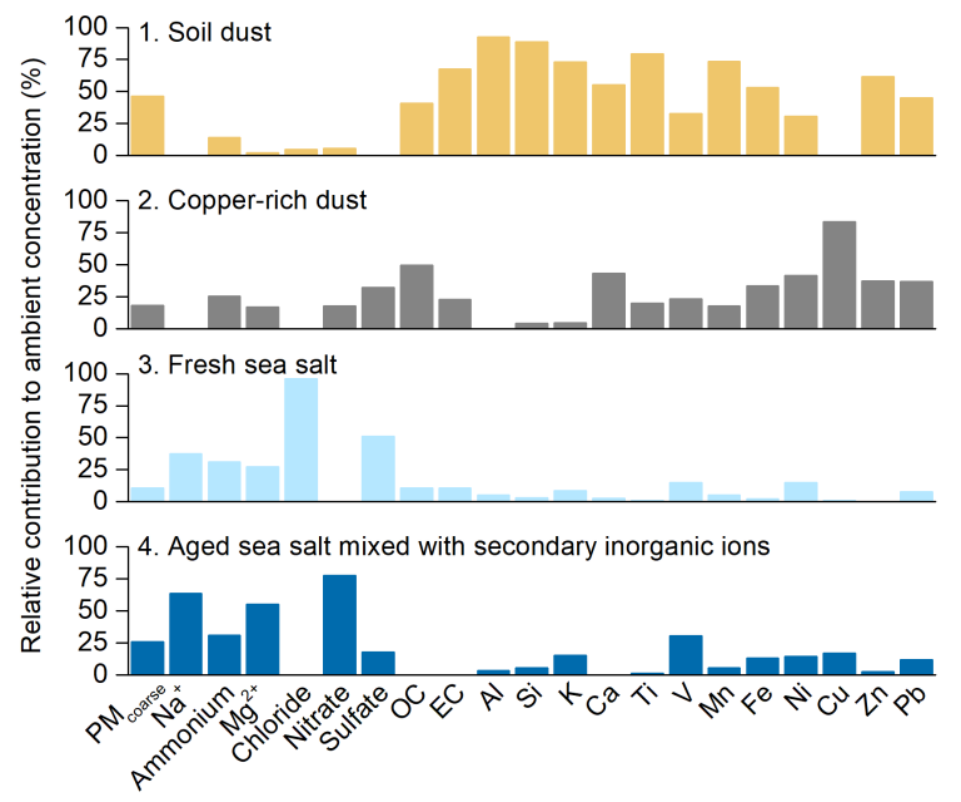

Figure 2. Factor profiles resolved by positive matrix factorization for source apportionment of PMcarse measured at Tuen Mun Air Quality Monitoring Station in Hong Kong.

\subsubsection{Characterization of the unidentified PMcoarse mass}

The total $\mathrm{PM}_{\text {coarse }}$ mass was incorporated in PMF modeling. The apportioned masses show an excellent agreement with measurements, with $R^{2}$ value of 0.98 and slope of 1.04 (intercept $=-0.57$ ). A test run was performed to examine if including the total mass would affect the source apportioning. It shows that inclusion of total mass has a negligible impact on the PMF solution. Specifically, the apportioning of all individual species is unaffected after including PM $_{\text {coarse }}$ mass as a total variable (see Table $\mathrm{S} 1$ in the Supplement). The test result implies that the $\mathrm{PM}_{\text {coarse }}$ mass in its entirety can be explained by the resolved sources. Based on this finding, the unidentified mass can be allocated to the individual sources by taking the difference between the PMF-apportioned mass and reconstructed mass in individual factors.

The unidentified mass derived from PMF (average $=5.2 \mu \mathrm{g} \mathrm{m}^{-3}$ ) shows reasonable agreement with that from direct subtraction using speciation data (average $=4.1 \mu \mathrm{g} \mathrm{m}^{-3}$ ), with $\mathrm{R}^{2}$ of 0.70 and slope of 1.07. Fugitive dust represents the largest contributor 
265 to the unidentified mass, contributing $46 \%\left(2.4 \mu \mathrm{g} \mathrm{m}^{-3}\right)$. The contribution by Cu-rich dust is $23 \%\left(1.2 \mu \mathrm{g} \mathrm{m}^{-3}\right)$. Carbonate, a potentially important component in $\mathrm{PM}_{\text {coarse }}$, is typically enriched with dust particles. As carbonate was not measured in this study, its quantity is estimated by two methods. The first method assumes all the excess cationic charge is balanced by carbonate. This method gives an average contribution of $0.6 \mu \mathrm{g} \mathrm{m}^{-3}$. The second method assumes all Ca detected is in the form of $\mathrm{CaCO}_{3}$. The resulting carbonate contribution is $1.5 \mu \mathrm{g} \mathrm{m}^{-3}$ and is construed as the upper estimate. Considering Ca mostly exists in the soil dust and $\mathrm{Cu}$-rich dust factors, carbonate at most accounts for $42 \%$ of the unidentified mass in the combined dust factors $\left(3.6 \mu \mathrm{g} \mathrm{m}^{-3}\right)$, thus suggesting other unmeasured constituents exist.

A small amount of residue liquid water content (LWC) has been reported to be present in aerosol samples even at low relative humidity (RH) condition for gravimetric measurement. The thermodynamic equilibrium model ISORROPIA II (http://nenes.eas.gatech.edu/ISORROPIA) is applied to estimate the aerosol LWC under the RH and temperature conditions of gravimetric measurement in the balance laboratory (i.e., temperature $=22{ }^{\circ} \mathrm{C}, \mathrm{RH}=35 \%$ ) (Fountoukis and Nenes, 2007). The calculation is performed assuming an open system in which only aerosol phase concentrations are considered, and the aerosol is in metastable state. When comparing the LWC with individual soluble ions, including $\mathrm{Na}^{+}, \mathrm{Mg}^{2+}, \mathrm{K}^{+}, \mathrm{Ca}^{2+}, \mathrm{Cl}^{-}$, nitrate and sulfate (shown in Fig. S5 in the Supplement), we find moderate to strong correlations between LWC and ions associated with sea salt: $\mathrm{Na}^{+}, \mathrm{Mg}^{2+}, \mathrm{Cl}^{-}$, and nitrate $\left(\mathrm{R}^{2}=0.49-0.78\right)$. By contrast, sulfate, $\mathrm{Ca}^{2+}$, and $\mathrm{K}^{+}$appear to be less relevant $\left(\mathrm{R}^{2}<0.15\right)$. The results imply that sea salt components play a key role in governing the LWC in $\mathrm{PM}_{\text {coarse. }}$ The average LWC is estimated to be $1.2 \mu \mathrm{g} \mathrm{m}^{-3}$, which agrees with the unidentified mass $\left(1.6 \mu \mathrm{g} \mathrm{m}^{-3}\right)$ in the combined fresh and aged sea salt factors. The unidentified mass in aged sea salt mixed with secondary inorganic aerosols being higher than fresh sea salt ( 1.3 vs. $0.3 \mu \mathrm{g} \mathrm{m}^{-3}$ ) is in line with the fact that $\mathrm{NaNO}_{3}$ is more hygroscopic than $\mathrm{NaCl}$.

After including carbonate and residue LWC, about half of the PMF-apportioned PM mass remains unidentified, and this 285 fraction is mainly contributed by the two dust-related factors. The mass discrepancy is likely attributed to the underprediction of geological mass in the mass reconstruction method, which only accounts for oxides of crustal elements. It is documented that other mineral constituents can exist in soil dust. For example, a field study in Morocco showed that over half of the PM $\mathrm{Poarse}_{\mathrm{e}}$ mass was made up of silicates (Kandler et al., 2009). Silicates commonly exist as illite and chloritoid, which contain mineralbound water that is not considered in thermodynamic equilibrium model. Determining the missing components in the aerosol dust and achieving a mass closure require further investigation with different techniques (e.g., microscopy). Overall, the results from the preliminary analysis of unidentified mass are consistent with the established knowledge. It provides support to the source apportionment results for the observed coarse particulates in its entirety, forming a strong basis for understanding their source origins. 


\subsection{Source contributions to $\mathbf{P M}_{\text {coarse }}$}

\subsubsection{Seasonal variation}

Figure 3 presents the absolute and relative source contributions by season in ascending order of $\mathrm{PM}_{\text {coarse }}$ concentration. To better characterize the contribution by anthropogenic nitrogen oxides $\left(\mathrm{NO}_{\mathrm{x}}\right)$ emission, the secondary nitrate is extracted from all the PMF-resolved factors. The two nitrate-free sea salt factors are grouped into one sea salt factor. In summer when $\mathrm{PM}_{\text {coarse }}$ concentration is the lowest $\left(8.1 \mu \mathrm{g} \mathrm{m}^{-3}\right)$, sea salt represents the largest contributor, contributing $47 \%$ or $3.7 \mu \mathrm{g} \mathrm{m}^{-3}$ of the ambient $\mathrm{PM}_{\text {coarse }}$. Note that the source contribution is based on PMF-apportioned mass, thus the mass includes the contribution from residue LWC, which is mainly associated with enhanced uptake of water by aged sea salt aerosols. Soil dust represents the next important source, contributing $1.8 \mu \mathrm{g} \mathrm{m}^{-3}$ or $24 \%$. Cu-rich dust contributes $1.0 \mu \mathrm{g} \mathrm{m}^{-3}$ or $13 \%$. Secondary nitrate has a contribution of $1.2 \mu \mathrm{g} \mathrm{m}^{-3}$ or $16 \%$.

$\mathrm{PM}_{\text {coarse }}$ source composition changes gradually as $\mathrm{PM}_{\text {coarse }}$ concentration increases from summer to the first winter and spring, and finally to fall and second winter. The trend indicates fugitive dust is the key driver for the elevated $\mathrm{PM}_{\text {coarse. }}$ In the fall and the second winter, soil dust contributed 12.9-15.2 $\mu \mathrm{g} \mathrm{m}^{-3}(58-61 \%)$ to the ambient $\mathrm{PM}_{\text {coarse, }}$ whereas the $\mathrm{Cu}$-rich dust contributed 3.2-4.6 $\mathrm{g} \mathrm{m}^{-3}$ (14-18\%). The contribution by secondary nitrate is $2.4-2.7 \mu \mathrm{g} \mathrm{m}^{-3}$, accounting for 9-12\%. This secondary component exhibits the lowest relative contribution compared to the 16-19\% contribution observed in other seasons.
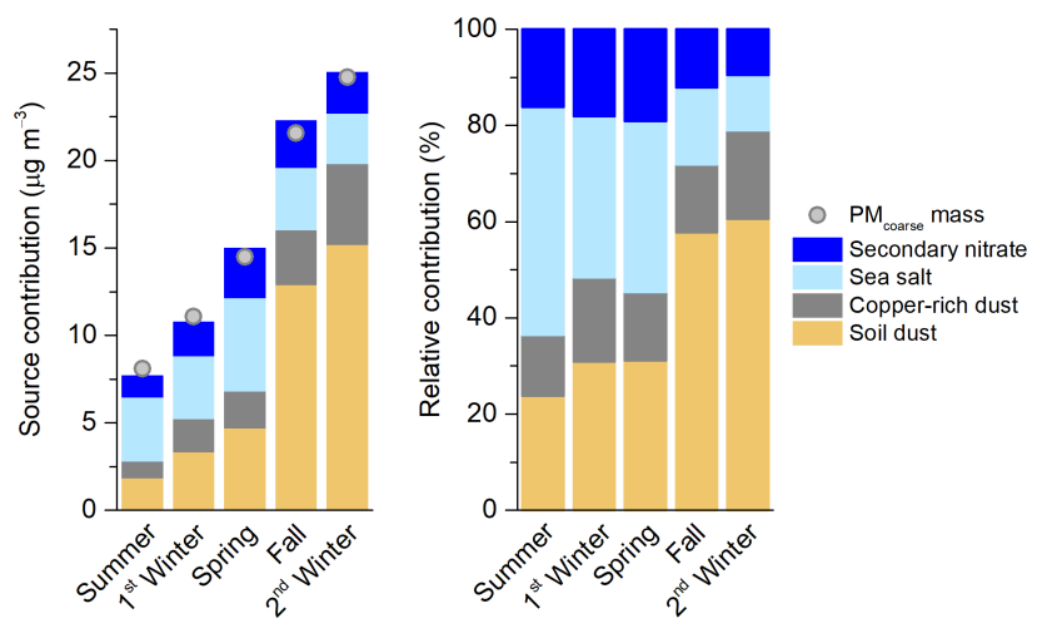

Figure 3. Source contributions to PMcarse during the study period. The left figure shows the results in $\mu \mathrm{g} \mathrm{m}^{-3}$ while the right shows the results in percentage share. The circle markers on the left figure represent the PMcoarse concentration measured by gravimetric analysis.

\subsubsection{Source contributions by air mass origins}

315 The association between air mass origins and source influence was investigated through backward air mass trajectory analysis. The back-trajectories were computed by the Hybrid Single-Particle Lagrangian Integrated Trajectory (HYSPLIT) model using 
meteorological data from the $1^{\circ}$ horizontal resolution Global Data Assimilation System (Stein et al., 2015). Past 48-hour backtrajectories of air mass reaching Hong Kong at $300 \mathrm{~m}$ height at the end of each sampling event at midnight were computed. The trajectories were clustered based on similarity between the trajectory endpoints. Four trajectory clusters are resolved, and the mean for each cluster are displayed in Fig. 4. The average source contributions associated with each cluster is also shown in the same figure.

The source contributions of $\mathrm{PM}_{\text {coarse }}$ associated with cluster 1 and 4 show contrasting features. Specifically, $\mathrm{PM}_{\text {coarse }}$ concentration at the monitoring site is the highest when the site is influenced by cluster 1, reaching an average of $21.2 \mu \mathrm{g} \mathrm{m}^{-3}$. During this period, the $\mathrm{PM}_{\text {coarse }}$ is mostly contributed by dust-related sources, with soil dust and $\mathrm{Cu}$-rich dust sources accounting for $72 \%$ and $18 \%$, respectively. Cluster 4 is under influence by marine air mass. The corresponding samples have an average $\mathrm{PM}_{\text {coarse }}$ concentration of $8.0 \mu \mathrm{g} \mathrm{m}^{-3}$, with sea salt being the largest contributor, accounting for $47 \%$. The two dust sources in total contributed to $38 \%$ of the $\mathrm{PM}_{\text {coarse }}$ mass. The total source contributions for cluster 2 and 3 are in between those of cluster 1 and 4, with source compositions reflecting the influence from the travelled source areas. By examining the individual trajectories in cluster 2 and 3, it can be seen cluster 2 is mostly composed of air masses passing through the coastal areas, 330 whereas cluster 3 consists of a mix of marine air masses from the east and short distance continental air masses from the northeast direction (see Fig. S6 in the Supplement). A common feature in cluster 2 and 3 is the relatively high contribution from secondary nitrate, which is 2 times or more higher than that in cluster 1 and 4 (2.5-3.0 $\left.\mu \mathrm{g} \mathrm{m}^{-3} \mathrm{vs.} 1.2-1.3 \mu \mathrm{g} \mathrm{m}^{-3}\right)$. Such a phenomenon could possibly be explained by the observation that cluster 2 and 3 have more mixed contributions from sea salt and $\mathrm{HNO}_{3}$, whereas for the other two clusters either there is a deficiency in the availability of sea salt as in cluster 1 or deficiency in $\mathrm{HNO}_{3}$ as in cluster 4 . 
(a)

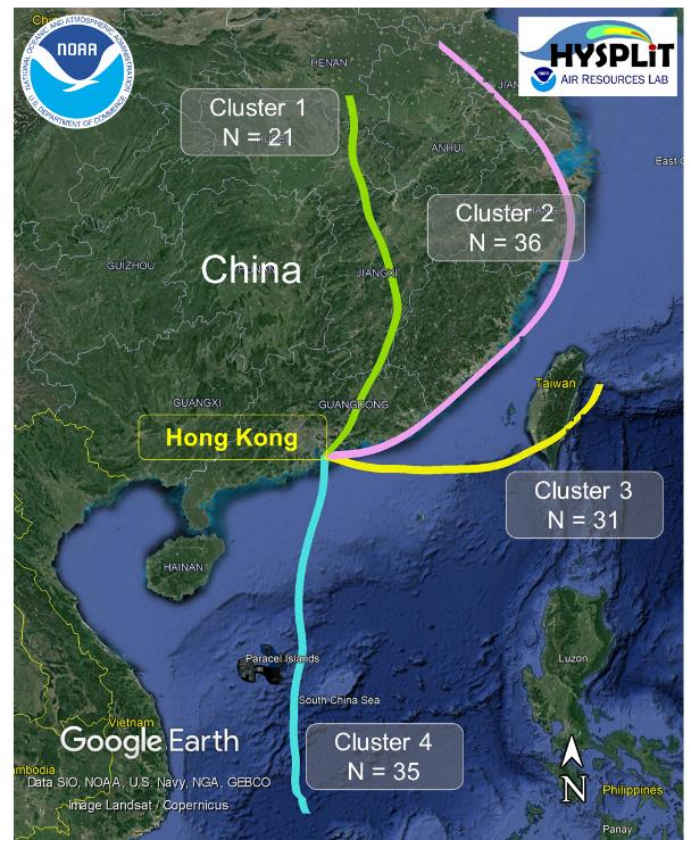

(b)

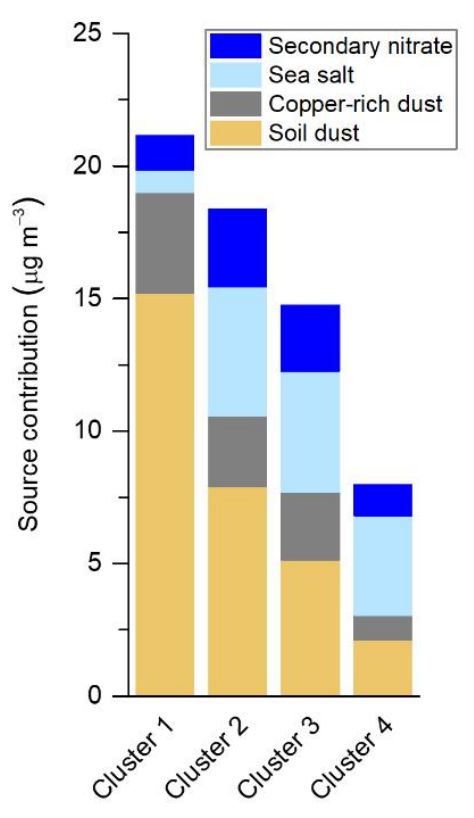

Figure 4. Source contributions to $\mathbf{P M}$ coarse grouped by air masses associated with different back-trajectory clusters. Past 48 -hour backward trajectory of air mass reaching Hong Kong (height $=300 \mathrm{~m}$ above ground level) during the end of each sampling event at midnight are considered. Figure (a) shows the mean trajectories of the four clustered trajectories (Map data: (C) Google Earth,

340 Data SIO, NOAA, U.S. Navy, NGA, GEBCO, Image Landsat/Copernicus) while Fig. (b) shows the source contributions for the corresponding clusters.

\subsubsection{Potential source regions}

The potential source areas are mapped by coupling the PMF-derived source contributions at the receptor with the associated backward air mass trajectory. In this analysis, the geographical domain of interest is divided and represented by a grid cell matrix. By coupling the trajectory endpoints in the grid cells with the concentrations at the receptor, each grid cell will receive a value representing the potential source strength in the corresponding area. The Concentration-Weighted Trajectory (CWT) method is applied for the analysis (Hsu et al., 2003). In this method, each grid cell receives a weighted concentration value obtained by averaging the sample concentration that has associated trajectories crossing the corresponding grid cell, weighted by the residence time of air mass in that grid cell. The weighted concentration value (or CWT value) is expressed by Eq. (1):

$C W T_{i j}=\frac{\sum_{l=1}^{L} C_{l} \tau_{i j l}}{\sum_{l=1}^{L} \tau_{i j l}}$

where $C_{l}$ is the concentration at the receptor site associated with back-trajectory $l, \tau_{i j l}$ is the number of endpoints of trajectory $l$ falling into gird cell $i, j$ (i.e., the residence time of the trajectory in the grid cell), and $L$ is the total number of trajectories over a time period. To improve the robustness of the CWT analysis, the input trajectory information was augmented by considering all the trajectories calculated every three hours for each sampling day and assuming the same concentrations over the day (Petit 
et al., 2017). The geographical domain was defined based on the spatial range of the trajectories traveled, with the dimension of grid cells set to be $0.5^{\circ} \times 0.5^{\circ}$. A weighting function was applied to down-weight grid cells with insufficient number of endpoints following the software guidelines. The CWT analysis was performed using the Zefir program (Petit et al., 2017). The analysis was performed by season to account for the potential variability in source strength and meteorological conditions. Figure 5 presents the CWT results for summer and the second winter and indicates the potential source areas. The results for other seasons are displayed in Fig. S7 in the Supplement. It can be seen that for the soil dust and Cu-rich dust sources, the elevated contributions are associated with continental air masses originated from the north, whereas the sea salt-related contributions are associated with marine and coastal air masses. These results are consistent with the general understanding of source origins of these categories of sources. An important finding revealed from this analysis is that the GBA or the greater part of southern China is shown to have significant fugitive dust-related emission sources and that these dust sources are implicated in causing days of high ambient $\mathrm{PM}_{\text {coarse }}$ loading in Hong Kong.

Study on the fugitive dust sources in the related region is limited. A study featuring hourly measurements of trace elements in $\mathrm{PM}_{\text {coarse }}$ and $\mathrm{PM}_{2.5}$ coupled with PMF source apportionment analysis in Foshan (an industrial city in the GBA) resolved two dust factors, with the first being a mixture containing road dust, brake wear, and tire wear, and the second being constructionrelated dust (Zhou et al., 2018). The two dust factors in that study show similar features as those resolved in this study.

370 Specifically, their road dust/brake wear/tire wear factor accounted for over half of the coarse Al, Si, K, Ca, Ti and Fe by mass. The construction dust factor differs from the road dust/brake wear/tire wear factor by its higher abundance of $\mathrm{Ca}$ than $\mathrm{Si}$. The enrichment in $\mathrm{Ca}$ is regarded as an indication of cementitious material commonly associated with construction activity. A point to note is that no $\mathrm{Cu}$ was measured by Zhou et al., hence it remains unclear to what extent the $\mathrm{Cu}$-rich dust factor resolved in this study is similar to the construction dust factor. Zhou et al. reported that the $\mathrm{PM}_{\text {coarse }}$ contributions by the road dust/brake wear/tire wear and construction dust sources were 17.7 and $9.4 \mu \mathrm{g} \mathrm{m}^{-3}$, respectively, during the seven-week monitoring in October-December 2014, higher than the 12.9-15.2 $\mu \mathrm{g} \mathrm{m}^{-3}$ and 3.2-4.6 $\mathrm{gg} \mathrm{m}^{-3}$ levels for the soil dust and Cu-rich dust factors during fall and second winter. This spatial gradient lends support to that the dust contributions in Hong Kong is associated with regional transport. Once entrained into the atmosphere, the lifetime of mineral dust can be up to several days and therefore it can be transported over long distance (over thousands of kilometers) and the concentration would decrease with transport distance away from the source regions. 


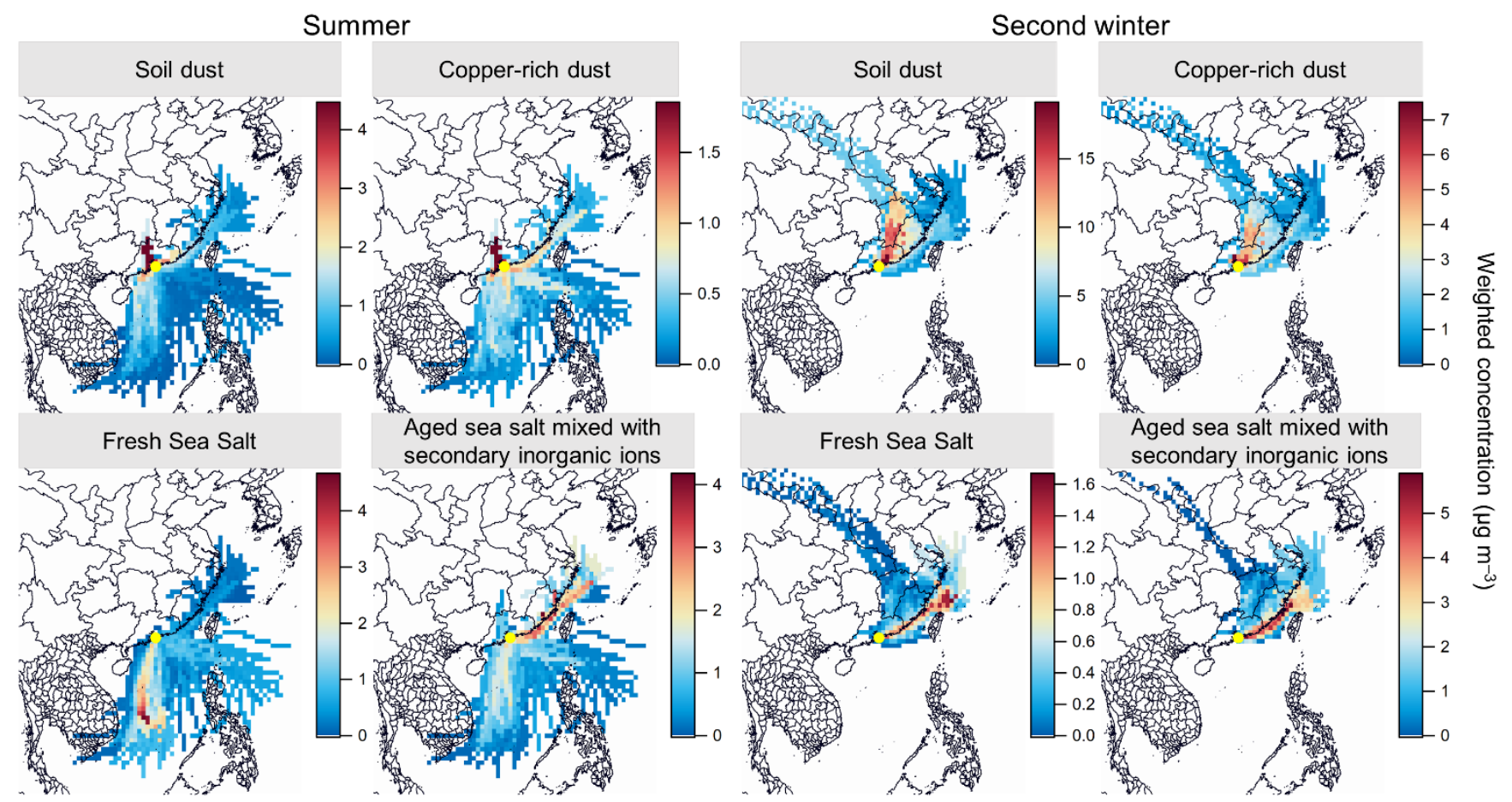

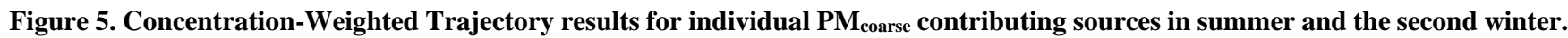
The location of the receptor site (Hong Kong) is represented by the yellow marker. The results for the other seasons are provided in Fig. 57 in the Supplement.

\subsection{Implications to atmospheric research and public health}

As indicated in two field studies measuring size segregated PM composition in Hong Kong, the distribution of nitrate in fine and coarse mode particles in coastal environment depends on the amount of gaseous $\mathrm{HNO}_{3}$ and alkaline particles (e.g., sea salt and soil dust) (Bian et al., 2014; Xue et al., 2014). The former is mainly controlled by the $\mathrm{NH}_{4} \mathrm{NO}_{3}-\mathrm{NH}_{3}+\mathrm{HNO}_{3}$ equilibrium that is closely related to fine particles $\mathrm{pH}$, temperature, and relative humidity, while the latter was shown to be more closely related to sea salt. The source apportionment analysis for $\mathrm{PM}_{\text {coarse }}$ in this study reaffirms sea salt plays a dominant role in the uptake of $\mathrm{HNO}_{3}$ in our coastal environment. Based on the PMF results, $77 \%$ of coarse nitrate is associated with sea salt, with the rest associated with fugitive dust. Despite the fact that fugitive dust-related aerosols represent a significant part of $\mathrm{PM}_{\text {coarse }}$ loading in our study area, this component has a less important role to play in coarse nitrate formation. Nonetheless, the results indicate that controlling $\mathrm{HNO}_{3}$ precursors would reduce nitrate in both $\mathrm{PM}_{2.5}$ and $\mathrm{PM}_{\text {coarse. }}$ A limitation to note is that the aerosol samples collected in this study were not corrected for sampling artifact of nitrate, which would affect the accuracy of the measured nitrate concentrations. The possible inter-particle interaction between fine and coarse particles on the $\mathrm{PM}_{10}$ samples is also neglected, which potentially bias the nitrate measurements in the two size modes. 
The comprehensive and high quality $\mathrm{PM}_{\text {coarse }}$ speciation and source apportionment results identify fugitive dust as the significant contributor to $\mathrm{PM}_{\text {coarse, }}$ especially during high $\mathrm{PM}_{\text {coarse }}$ days. It should be noted that the high loading of dust was not

caused by transient dust storm events, but occurred over the entire fall and winter season, indicating the constant emission of dust particles. A recent study conducted in northern China showed that coarse dust particles can act as a medium for rapid secondary inorganic and organic aerosols formation in highly polluted condition (Xu et al., 2020). Considering the southern China is more humid than northern China, our study region presents an atmospheric condition different from that in Xu et al.'s study, which is more favourable to adsorption of water on mineral dust, and consequently lead to different impacts on atmospheric chemistry and climate (Tang et al., 2016). In this study, $90 \%$ of coarse OC are apportioned to the two dust-related factors by PMF. Given both $\mathrm{PM}_{2.5}$ and $\mathrm{PM}_{\text {coarse }}$ in our study region typically experience long transport distance, more detailed speciation on organic markers might be helpful in elucidating the natural vs. anthropogenic and primary vs. secondary nature of the organics in $\mathrm{PM}_{\text {coarse. }}$

Accumulative evidence has shown the positive link between adverse health effects and $\mathrm{PM}_{\text {coarse }}$ exposure. Nationwide studies in China have provided evidence for the association between short-term exposure to $\mathrm{PM}_{\text {coarse }}$ and mortality and reduced pulmonary function in adult asthmatic patients (Chen et al., 2019; Lei et al., 2022). These studies indicate a stronger association in southern China compared to the northern part, which might be attributed to the difference in the source composition. For example, dust aerosols in the north typically contain higher proportion of windblown dust from natural sources while those in the south might have larger influence from industrial and traffic-related emissions. Oxidative potential of PM has been shown to be a useful metric for PM health impact. Copper and humic-like substances (HULIS) are important active species in catalysing the formation of reactive oxygen species leading to oxidative stress in human body (Lin and Yu, 2011; Bates et al., 2019). The former is likely found in industrial emissions and non-tailpipe emissions (brake/tire wear) while the latter are likely associated with biological material in soil. In this study, the average concentrations of fine and coarse mode $\mathrm{Cu}$ are comparable, being $8.1 \pm 5.4$ and $7.6 \pm 4.7 \mathrm{ng} \mathrm{m}^{-3}$, respectively. Given that $\mathrm{Cu}$ is the important species governing the response of acellular assay for PM oxidative potential measurement, the similar magnitude in concentration calls for further investigation into the sources and potential health effects of $\mathrm{PM}_{\text {coarse. }}$.

\section{Conclusions}

$\mathrm{PM}_{\text {coarse }}$ has an important role to play in formulating policies to control $\mathrm{PM}_{10}$ given its growing relative contribution to $\mathrm{PM}_{10}$ loading in urban atmospheres. We have conducted the first joint chemical speciation of $\mathrm{PM}_{10}$ and $\mathrm{PM}_{2.5}$ in Hong Kong, a coastal and highly urbanized city in southern China. This enables us to derive a high quality $\mathrm{PM}_{\text {coarse }}$ composition data set spanning a 1 year long period from January 2020 to February 2021. The annual average concentration of $\mathrm{PM}_{\text {coarse }}$ is $14.9 \pm 8.6$ $\mu \mathrm{g} \mathrm{m}^{-3}$ ( \pm standard deviation), representing nearly half (45 \%) of ambient $\mathrm{PM}_{10}\left(32.9 \pm 18.5 \mu \mathrm{g} \mathrm{m}^{-3}\right.$ ). The $\mathrm{PM}_{\text {coarse }}$ also exhibit a 
large seasonal variation, ranging from $8.1 \mu \mathrm{g} \mathrm{m}^{-3}$ in summer to $24.8 \mu \mathrm{g} \mathrm{m}^{-3}$ in the second winter period. Meteorological data suggest the seasonal contrast is driven by the variations in emission pattern and/or air mass origin.

Among the measured constituents, geological material calculated by assuming oxides of crustal elements represents the largest $\mathrm{PM}_{\text {coarse }}$ component (35\%), followed by nitrate (15\%), sea salt ions (11\%) and organics (8\%). A quarter of PMcoarse mass $\left(4.1 \mu \mathrm{g} \mathrm{m}^{-3}\right)$ was regarded as unidentified mass according to a mass closure analysis. Positive matrix factorization analysis apportioned the $\mathrm{PM}_{\text {coarse }}$ mass to four sources, including soil dust, $\mathrm{Cu}$-rich dust, fresh sea salt, and aged sea salt mixed with secondary inorganic aerosols. Additionally, these four sources are able to account for the unidentified mass. The results show that $\sim 70 \%$ of the unidentified mass is associated with the two dust factors, while the rest is residue liquid water content as implied from thermodynamic modeling using ISORROPIA II.

The $\mathrm{PM}_{\text {coarse }}$ concentration and corresponding source contributions show notable variations among samples influenced by different air mass origins. Specifically, the $\mathrm{PM}_{\text {coarse }}$ concentration was averaged at $8.0 \mu \mathrm{g} \mathrm{m}^{-3}$ when the site was influenced by marine air mass, with sea salt components being the largest contributor (47\%), followed by the two dust factors (38\% in total). Significant elevation in $\mathrm{PM}_{\text {coarse }}$ concentration was observed when the site was under the influences of air masses from the northern continental region, reaching $21.2 \mu \mathrm{g} \mathrm{m}^{-3}$. The increase was largely driven by the enhanced contribution from the soil dust and Cu-rich dust factors, which contributed to $90 \%$ of the PM mass in total.

The source contribution and back-trajectory results were coupled and analyzed by the Concentration-Weighted Trajectory method to map the potential source areas. The results show that either the Greater Bay Area or the greater part of southern 445 China have a source intensity of fugitive dust-related emissions sufficiently large to result in the high ambient PM $_{\text {coarse }}$ loadings in Hong Kong, especially when the meteorological condition is favourable to regional transport of air pollutants. This study identified several aspects for further $\mathrm{PM}_{\text {coarse }}$ or $\mathrm{PM}_{10}$ research, including pinpointing the exact dust generation processes leading to the high $\mathrm{PM}_{\text {coarse }}$ loadings in the study region, elucidating the roles of coarse particles in mediating secondary aerosol formation, and examining the potential health burden of $\mathrm{PM}_{\text {coarse }}$ exposure through oxidative potential measurement. 
450 Data availability. Chemical composition data presented in this study can be requested by emailing enquiry@epd.gov.hk or contacting the corresponding authors (envrykwong@ust.hk; jian.yu@ust.hk).

Author contribution. YKW, JZY and KKML formulated the overall design of the study. YKW, KML, and CY carried out the chemical analyses. YKW analyzed the data with contributions from JZY and KKML. YKW and JZY prepared the manuscript with contributions from all co-authors.

Competing interests. The authors declare that they have no conflict of interest.

Disclaimer. The content of this paper does not necessarily reflect the views and policies of the HKSAR Government, nor does mention of trade names or commercial products constitute an endorsement or recommendation of their use.

Acknowledgements. This work is supported by the Hong Kong Environmental Protection Department (HKEPD) (tender refs. 19-01121 and 19-01177). We thank Robert Tang and Rebecca Kwan of HKEPD for their inputs and assistance in project logistics. We gratefully acknowledge the NOAA Air Resources Laboratory (ARL) for the provision of the HYSPLIT transport and dispersion model used in this publication.

\section{References}

Adar, S. D., Filigrana, P. A., Clements, N., and Peel, J. L.: Ambient coarse particulate matter and human health: A systematic review and meta-analysis, Curr. Environ. Health Rep., 1, 258-274, https://doi.org/10.1007/s40572-014-0022-z, 2014.

465 Bates, J. T., Fang, T., Verma, V., Zeng, L. H., Weber, R. J., Tolbert, P. E., Abrams, J. Y., Sarnat, S. E., Klein, M., Mulholland, J. A., and Russell, A. G.: Review of acellular assays of ambient particulate matter oxidative potential: Methods and relationships with composition, sources, and health effects, Environ. Sci. Technol., 53, 4003-4019, https://doi.org/10.1021/acs.est.8b03430, 2019.

Bian, Q. J., Huang, X. H. H., and Yu, J. Z.: One-year observations of size distribution characteristics of major aerosol

470 constituents at a coastal receptor site in Hong Kong - Part 1: Inorganic ions and oxalate, Atmos. Chem. Phys., 14, 9013-9027, https://doi.org/10.5194/acp-14-9013-2014, 2014.

Chen, R. J., Yin, P., Meng, X., Wang, L. J., Liu, C., Niu, Y., Liu, Y. N., Liu, J. M., Qi, J. L., You, J. L., Kan, H. D., and Zhou, M. G.: Associations between coarse particulate matter air pollution and cause-specific mortality: A nationwide analysis in 272 Chinese cities, Environ. Health Perspect., 127, 017008, https://doi.org/10.1289/ehp2711, 2019.

475 Cheng, Y., Lee, S. C., Gu, Z. L., Ho, K. F., Zhang, Y. W., Huang, Y., Chow, J. C., Watson, J. G., Cao, J. J., and Zhang, R. J.: $\mathrm{PM}_{2.5}$ and $\mathrm{PM}_{10-2.5}$ chemical composition and source apportionment near a Hong Kong roadway, Particuology, 18, 96-104, https://doi.org/10.1016/j.partic.2013.10.003, 2015. 
Cheung, K., Daher, N., Kam, W., Shafer, M. M., Ning, Z., Schauer, J. J., and Sioutas, C.: Spatial and temporal variation of chemical composition and mass closure of ambient coarse particulate matter $\left(\mathrm{PM}_{10-2.5}\right)$ in the Los Angeles area, Atmos. Environ., 45, 2651-2662, https://doi.org/10.1016/j.atmosenv.2011.02.066, 2011.

Chow, J. C. and Watson, J. G.: Guideline on speciated particulate monitoring, prepared by Desert Research Institute, Reno, NV, for the U. S. Environmental Protection Agency, Research Triangle Park, NC, 1998.

Chow, J. C., Watson, J. G., Chen, L. W. A., Chang, M. C. O., Robinson, N. F., Trimble, D., and Kohl, S.: The IMPROVE_A temperature protocol for thermal/optical carbon analysis: maintaining consistency with a long-term database, J. Air Waste Manage., 57, 1014-1023, https://doi.org/10.3155/1047-3289.57.9.1014, 2007.

Clements, A. L., Fraser, M. P., Upadhyay, N., Herckes, P., Sundblom, M., Lantz, J., and Solomon, P. A.: Chemical characterization of coarse particulate matter in the Desert Southwest - Pinal County Arizona, USA, Atmos. Pollut. Res., 5, 52-61, https://doi.org/10.5094/APR.2014.007, 2014.

Cohen, D. D., Garton, D., Stelcer, E., Hawas, O., Wang, T., Poon, S., Kim, J., Choi, B. C., Oh, S. N., Shin, H. J., Ko, M. Y., and Uematsu, M.: Multielemental analysis and characterization of fine aerosols at several key ACE-Asia sites, J. Geophys. Res.-Atmos., 109, D19S12, https://doi.org/10.1029/2003JD003569, 2004.

Daher, N., Ruprecht, A., Invernizzi, G., De Marco, C., Miller-Schulze, J., Heo, J. B., Shafer, M. M., Shelton, B. R., Schauer, J. J., and Sioutas, C.: Characterization, sources and redox activity of fine and coarse particulate matter in Milan, Italy, Atmos. Environ., 49, 130-141, https://doi.org/10.1016/j.atmosenv.2011.12.011, 2012.

Fountoukis, C. and Nenes, A.: ISORROPIA II: A computationally efficient thermodynamic equilibrium model for $\mathrm{K}^{+}-\mathrm{Ca}^{2+}$ $\mathrm{Mg}^{2+}-\mathrm{NH}_{4}{ }^{+}-\mathrm{Na}^{+}-\mathrm{SO}_{4}{ }^{2-}-\mathrm{NO}_{3}{ }^{-}-\mathrm{Cl}^{-}-\mathrm{H}_{2} \mathrm{O}$ aerosols, Atmos. Chem. Phys., 7, 4639-4659, https://doi.org/10.5194/acp-7-46392007, 2007.

Hand, J. L., Gill, T. E., and Schichtel, B. A.: Urban and rural coarse aerosol mass across the United States: Spatial and seasonal variability and long-term trends, Atmos. Environ., 218, 117025, https://doi.org/10.1016/j.atmosenv.2019.117025, 2019.

Harrison, R. M., Jones, A. M., and Lawrence, R. G.: Major component composition of $\mathrm{PM}_{10}$ and $\mathrm{PM}_{2.5}$ from roadside and urban background sites, Atmos. Environ., 38, 4531-4538, https://doi.org/10.1016/j.atmosenv.2004.05.022, 2004.

HKEPD: Air quality in Hong Kong 2019, Hong Kong Environmental Protection Department, Hong Kong, https://www.aqhi.gov.hk/api_history/english/report/files/AQR2019e_final.pdf, 2020.

Ho, K. F., Lee, S. C., Chow, J. C., and Watson, J. G.: Characterization of $\mathrm{PM}_{10}$ and $\mathrm{PM}_{2.5}$ source profiles for fugitive dust in

Hong Kong, Atmos. Environ., 37, 1023-1032, https://doi.org/10.1016/S1352-2310(02)01028-2, 2003.

Hsu, Y. K., Holsen, T. M., and Hopke, P. K.: Comparison of hybrid receptor models to locate PCB sources in Chicago, Atmos. Environ., 37, 545-562, https://doi.org/10.1016/S1352-2310(02)00886-5, 2003.

Huang, X. H. H., Bian, Q. J., Ng, W. M., Louie, P. K. K., and Yu, J. Z.: Characterization of PM 2.5 major components and source investigation in suburban Hong Kong: A one year monitoring study, Aerosol Air Qual. Res., 14, 237-250, https://doi.org/10.4209/aaqr.2013.01.0020, 2014. 
Hueglin, C., Gehrig, R., Baltensperger, U., Gysel, M., Monn, C., and Vonmont, H.: Chemical characterisation of PM $2.5, \mathrm{PM}_{10}$ and coarse particles at urban, near-city and rural sites in Switzerland, Atmos. Environ., 39, 637-651, https://doi.org/10.1016/j.atmosenv.2004.10.027, 2005.

Jiang, S. Y. N., Gali, N. K., Yang, F. H., Zhang, J. K., and Ning, Z.: Chemical characterization of size-segregated PM from different public transport modes and implications of source specific contribution to public exposure, Environ. Sci. Pollut. Res., 24, 20029-20040, https://doi.org/10.1007/s11356-017-9661-6, 2017.

Kandler, K., Schütz, L., Deutscher, C., Ebert, M., Hofmann, H., Jäckel, S., Jaenicke, R., Knippertz, P., Lieke, K., Massling, A., Petzold, A., Schladitz, A., Weinzierl, B., Wiedensohler, A., Zorn, S., and Weinbruch, S.: Size distribution, mass concentration, chemical and mineralogical composition and derived optical parameters of the boundary layer aerosol at Tinfou, Morocco, during SAMUM 2006, Tellus B, 61, 32-50, https://doi.org/10.1111/j.1600-0889.2008.00385.x, 2009.

Lei, J., Yang, T., Huang, S. J., Li, H. C., Zhu, Y. X., Gao, Y., Jiang, Y. X., Wang, W. D., Liu, C., Kan, H. D., and Chen, R. J.: Hourly concentrations of fine and coarse particulate matter and dynamic pulmonary function measurements among 4992 adult asthmatic patients in 25 Chinese cities, Environ. Int., 158, 106942, https://doi.org/10.1016/j.envint.2021.106942, 2022.

Lin, P. and Yu, J. Z.: Generation of reactive oxygen species mediated by humic-like substances in atmospheric aerosols, Environ. Sci. Technol., 45, 10362-10368, https://doi.org/10.1021/es2028229, 2011.

Louie, P. K. K., Watson, J. G., Chow, J. C., Chen, A., Sin, D. W., and Lau, A. K.: Seasonal characteristics and regional transport of $\mathrm{PM}_{2.5}$ in Hong Kong, Atmos. Environ., 39, 1695-1710, https://doi.org/10.1016/j.atmosenv.2004.11.017, 2005. Norris, G., Duvall, R., Brown, S., and Bai, S.: EPA Positive Matrix Factorization (PMF) 5.0 fundamentals and user guide, prepared for the U. S. Environmental Protection Agency, Office of Research and Development, Washington, DC, https://www.epa.gov/sites/default/files/2015-02/documents/pmf_5.0_user_guide.pdf, 2014.

Paatero, P. and Tapper, U.: Positive matrix factorization: A non-negative factor model with optimal utilization of error estimates of data values, Environmetrics, 5, 111-126. https://doi.org/10.1002/env.3170050203, 1994.

Pant, P. and Harrison, R. M.: Estimation of the contribution of road traffic emissions to particulate matter concentrations from field measurements: A review, Atmos. Environ., 77, 78-97, https://doi.org/10.1016/j.atmosenv.2013.04.028, 2013.

Petit, J. E., Favez, O., Albinet, A., and Canonaco, F.: A user-friendly tool for comprehensive evaluation of the geographical origins of atmospheric pollution: Wind and trajectory analyses, Environ. Model. Softw., 88, 183-187, https://doi.org/10.1016/j.envsoft.2016.11.022, 2017.

Putaud, J. P., Van Dingenen, R., Alastuey, A., Bauer, H., Birmili, W., Cyrys, J., Flentje, H., Fuzzi, S., Gehrig, R., Hansson, H. C., Harrison, R. M., Herrmann, H., Hitzenberger, R., Hüglin, C., Jones, A. M., Kasper-Giebl, A., Kiss, G., Kousa, A., 540 Kuhlbusch, T. A. J., Löschau, G., Maenhaut, W., Molnar, A., Moreno, T., Pekkanen, J., Perrino, C., Pitz, M., Puxbaum, H., Querol, X., Rodriguez, S., Salma, I., Schwarz, J., Smolik, J., Schneider, J., Spindler, G., Brink, H. T., Tursic, J., Viana,M., Wiedensohler, A., and Raes, F.: A European aerosol phenomenology - 3: Physical and chemical characteristics of particulate 
matter from 60 rural, urban, and kerbside sites across Europe, Atmos. Environ., 44, 1308-1320, https://doi.org/10.1016/j.atmosenv.2009.12.011, 2010.

Stein, A. F., Draxler, R. R., Rolph, G. D., Stunder, B. J., Cohen, M. D., and Ngan, F.: NOAA's HYSPLIT atmospheric transport and dispersion modeling system, Bull. Am. Meteorol. Soc., 96, 2059-2077, https://doi.org/10.1175/BAMS-D-14-00110.1, 2015.

Stone, E., Schauer, J., Quraishi, T. A., and Mahmood, A.: Chemical characterization and source apportionment of fine and coarse particulate matter in Lahore, Pakistan, Atmos. Environ., 44, 1062-1070, https://doi.org/10.1016/j.atmosenv.2009.12.015, 2010.

Tang, M., Cziczo, D. J., and Grassian, V. H.: Interactions of water with mineral dust aerosol: water adsorption, hygroscopicity, cloud condensation, and ice nucleation, Chem. Rev., 116, 4205-4259, https://doi.org/10.1021/acs.chemrev.5b00529, 2016. USEPA: Integrated Science Assessment for Particulate Matter, the U.S. Environmental Protection Agency, Research Triangle Park, NC, https://www.epa.gov/isa/integrated-science-assessment-isa-particulate-matter, 2019.

$\mathrm{Wu}, \mathrm{C}$. and Yu, J. Z.: Evaluation of linear regression techniques for atmospheric applications: The importance of appropriate weighting, Atmos. Meas. Tech., 11, 1233-1250, https://doi.org/10.5194/amt-11-1233-2018, 2018.

Xu, W. Y., Kuang, Y., Liang, L. L., He, Y., Cheng, H. B., Bian, Y. X., Tao, J. C., Zhang, G., Zhao, P. S., Ma, N., Zhao, H. R., Zhou, G. S., Su, H., Cheng, Y. F., Xu, X. B., Shao, M., and Sun, Y.: Dust-dominated coarse particles as a medium for rapid secondary organic and inorganic aerosol formation in highly polluted air, Environ. Sci. Technol., 54, 15710-15721, https://doi.org/10.1021/acs.est.0c07243, 2020.

Xue, J., Yuan, Z. B., Lau, A. K. H., and Yu, J. Z.: Insights into factors affecting nitrate in $\mathrm{PM}_{2.5}$ in a polluted high $\mathrm{NO}_{\mathrm{x}}$ environment through hourly observations and size distribution measurements, J. Geophys. Res.-Atmos., 119, 4888-4902, http://dx.doi.org/10.1002/2013JD021108, 2014.

Yu, J. Z. and Zhang, T.: Chemical speciation of $\mathrm{PM}_{2.5}$ filter samples - January 1 through December 31, 2017, Final report submitted to the Hong Kong Environmental Protection Department, The Government of the Hong Kong Special Administrative Region, 2018.

Yu, J. Z., Tung, J. W. T., Wu, A. W. M., Lau, A. K. H., Louie, P. K. K., and Fung, J. C. H.: Abundance and seasonal characteristics of elemental and organic carbon in Hong Kong PM $\mathrm{P}_{10}$, Atmos. Environ., 38, 1511-1521, https://doi.org/10.1016/j.atmosenv.2003.11.035, 2004.

570 Zhang, X. X., Yuan, Z. B., Li, W. S., Lau, A. K. H., Yu, J. Z., Fung, J. C. H., Zheng, J. Y., and Yu, A. L. C.: Eighteen-year trends of local and non-local impacts to ambient $\mathrm{PM}_{10}$ in Hong Kong based on chemical speciation and source apportionment, Atmos. Res., 214, 1-9, https://doi.org/10.1016/j.atmosres.2018.07.004, 2018.

Zhou, S. Z., Davy, P. K., Huang, M. J., Duan, J. B., Wang, X. M., Fan, Q., Chang, M., Liu, Y. M., Chen, W. H., Xie, S. J., Ancelet, T., and Trompetter, W. J.: High-resolution sampling and analysis of ambient particulate matter in the Pearl River 
https://doi.org/10.5194/acp-2021-1030

Preprint. Discussion started: 22 December 2021

(C) Author(s) 2021. CC BY 4.0 License.

(c) (i)

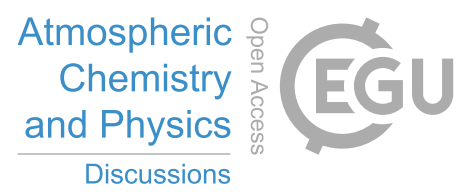

575 Delta region of southern China: Source apportionment and health risk implications, Atmos. Chem. Phys., 18, 2049-2064, https://doi.org/10.5194/acp-18-2049-2018, 2018. 